\title{
Tobacco advertising, promotion and sponsorship in entertainment media: a phenomenon requiring stronger controls in the Eastern Mediterranean Region
}

Fatimah M.S. El-Awa ${ }^{1}$, Randa Abou El Naga ${ }^{2}$, Sahar Labib ${ }^{3}$ and Nisreen Abdel Latif 4

${ }^{1}$ Tobacco Free Initiative, World Health Organization, Regional Office for the Eastern Mediterranean, Cairo, Egypt (Correspondence to: Fatimah M.S. El-Awa: elawaf@who.int). ${ }^{2}$ Egypt Country Office, World Health Organization, Cairo, Egypt. ${ }^{3}$ Tobacco Control Department, Ministry of Health and Population, Cairo, Egypt. ${ }^{4}$ Noncommunicable Diseases \& Mental Health, World Health Organization, Regional Office for the Eastern Mediterranean, Cairo, Egypt.

\begin{abstract}
Tobacco use and placement of tobacco products in television (TV) productions and movies is a way to promote tobacco use while avoiding tobacco advertising bans that exist in most countries. The fact that such productions are broadcast widely and viewed by millions, including children and young people, is of concern. This paper reviews the evidence on the use of tobacco advertising, promotion and sponsorship (TAPS) in TV and films in the Eastern Mediterranean Region and the ways to combat it. Evidence from Egypt shows considerable and increasing use of tobacco products by actors on screen, including female actors, in programmes aired during Ramadan in 2015-2017. A study of Iranian movies in 2015 showed that tobacco scenes in Iranian movies were increasing. In 2014, the WHO Regional Office for the Eastern Mediterranean held a consultative meeting on TAPS in drama. The consultation recommended regulating the tobacco presence in movies and TV through complete implementation of Article 13 of the WHO FCTC, and raising the issue to the WHO FCTC Conference of the Parties. In 2016, the Conference of the Parties called on parties to consider scaling up the implementation of WHO FCTC Article 13 and monitoring the use of TAPS in entertainment media in accordance with national legislation. A comprehensive approach is essential to end the tobacco industry's use of TV productions and movies to promote their products.
\end{abstract}

Keywords: tobacco; smoking; noncommunicable diseases; FCTC; media

Citation: El-Awa F, Abou El Naga R, Labib S, Latif N. Tobacco advertising, promotion and sponsorship in entertainment media: a phenomenon requiring stronger controls in the Eastern Mediterranean Region. East Mediterr Health J. 2018;24(1):72-76. https://doi.org/10.26719/2018.24.1.72

Received: 28/09/17; accepted: 13/11/17

Copyright (C) World Health Organization (WHO) 2018. Some rights reserved. This work is available under the CC BY-NC-SA 3.0 IGO license (https:// creativecommons.org/licenses/by-nc-sa/3.o/igo)

\section{Introduction}

In 2014 the extensive tobacco use and placement of tobacco products in television (TV) productions in many countries and satellite channels airing across the Eastern Mediterranean Region (EMR) was noted. In response, the World Health Organization Regional Office for the Eastern Mediterranean (EMRO) held a consultative meeting on tobacco advertising, promotion and sponsorship (TAPS) in entertainment media. In its recommendations (1), EMRO highlighted two important measures: first, countries needed to continue monitoring TAPS in the entertainment media; and second, EMR parties to the WHO Framework Convention on Tobacco Control (FCTC) should raise this problem to the level of the WHO FCTC Conference of the Parties (2).

\section{The problem}

Since the consultation, 3 reports have been released by the Egyptian Fund for Combating and Treatment of Addiction and Drug Abuse (http://drugcontrol.org.eg/), which studied TAPS in TV dramas aired in the month of Ramadan in 2015-2017 (3).

Ramadan was selected as the focus of these 3 reports because, over the past 10 years, it has been the practice of
TV producers to make TV series specifically for broadcast during this period. Each series has 30 episodes (one for each day of the month of Ramadan) and each episode, when combined with advertisements aired every 15-20 minutes, lasts $45-60$ minutes. In 2017, it was estimated that 33 series were produced for Ramadan in Egypt alone, while other countries, such as Kuwait, Lebanon and the Syrian Arab Republic also made TV programmes for Ramadan.

The reports monitored all TV production in $2015(24$ series), 2016 (29 series) and 2017 (33 series). The findings showed considerable use of tobacco products. In 2015, of the total airing duration in the selected sample, $10 \%$ showed tobacco use by one or more actors. In 2016, 9\% showed tobacco use by one or more actors and in 2017, 13\% showed tobacco use by one or more actors.

Female smoking was high throughout the 3 years: in $2015,18.3 \%$ of female actors smoked, in 2016, $19.7 \%$ smoked, while in $2017,15.0 \%$ of female actors smoked. In the 2015 study, only $4.2 \%$ of the series produced for airing during Ramadan did not show tobacco use. In 2016 and 2017, tobacco use was shown in all the series. The 2016 study showed that $74 \%$ of smoking scenes featured cigarette use, $16.7 \%$ showed waterpipe use, $9 \%$ showed cigar use 
and $2.3 \%$ showed electronic cigarette use. The use of more than one tobacco product was sometimes shown in the same scene.

Tobacco use in entertainment productions is not limited to Arabic-speaking countries in the Region or restricted to series airing during Ramadan. A study of Iranian movies conducted in 2015 showed that tobacco scenes in Iranian movies were increasing over time (4). An editorial in The Lancet also noted that despite the WHO FCTC's commitment to ban tobacco advertising, promotion and sponsorship, "film remains a potent way of exposing young people to images of smoking without restrictions" (5). The most recent data from the Global Youth Tobacco Survey show that despite the ban on direct tobacco advertising in many countries, a very high proportion of 13-15-year-olds in the EMR see tobacco use on TV (Figure 1).

The problem of the use of TV series and films to promote tobacco is a global one. However, the situation in the EMR has certain regional characteristics. For example, TV series focus on the month of Ramadan, during which people relax in front of the TV after breaking their fast (after sunset). These broadcast hours have a substantial number of scenes with all forms of tobacco use, including waterpipe, cigar and, more recently, electronic cigarettes. This may promote tobacco use in non-users and encourage smokers to smoke more by portraying it as an enjoyable, relaxing activity; this would produce more second-hand smoke for those who are not smokers. Moreover, it seems that this practice is attempting to create new realities: for example, the average regional prevalence of tobacco use among women does not exceed $4 \%(6)$, but in TV series aired during Ramadan in $2016,19.7 \%$ of female actors smoked. Furthermore, recent productions have introduced new types of tobacco; it has been reported that the first time electronic cigarettes were featured in TV productions was in Ramadan in 2016.
It is important to note that nearly all countries in the EMR have a legal ban on direct advertising of tobacco use (apart from Somalia). Promoting tobacco use through TV productions, in the ways described above, is an obvious way to undermine these bans. Placing tobacco use within scenes in TV series and films completely circumvents the bans. These productions are not only broadcast widely in most countries in the Region but are accessible to all age groups (7). This situation is not limited to the EMR, as it is seen in other countries as well (8).

Although there is no firm evidence that the tobacco industry is paying for product placement in Ramadan TV series, the extensive use of tobacco in these series raises suspicions about the forces behind such a phenomenon As yet, no studies have assessed the effect of scenes showing tobacco use on youth in the Region. However, evidence from outside the Region shows that there is a strong link between youth smoking and tobacco use in films. For example, in a report by the Centers for Disease Control and Prevention on the situation in the United States of America, it is suggested that "An R rating for movies with tobacco use could potentially reduce the number of teen smokers by $18 \%$ and prevent their premature deaths from tobacco-related diseases" (9). There is nothing to suggest that evidence from the EMR would contradict this.

\section{Way forward}

From evidence gathered globally, it is now clear that exposure to on-screen smoking results in the initiation of smoking by youths (10). Thus, for successful tobacco control, it is essential to control (including banning) tobacco use in films and TV productions.

While over the past 10 years the number of TV series produced specifically for Ramadan has increased and the number of tobacco-use scenes in these series has also risen (3), the TAPS phenomenon must be addressed in the broader context of entertainment productions in general.

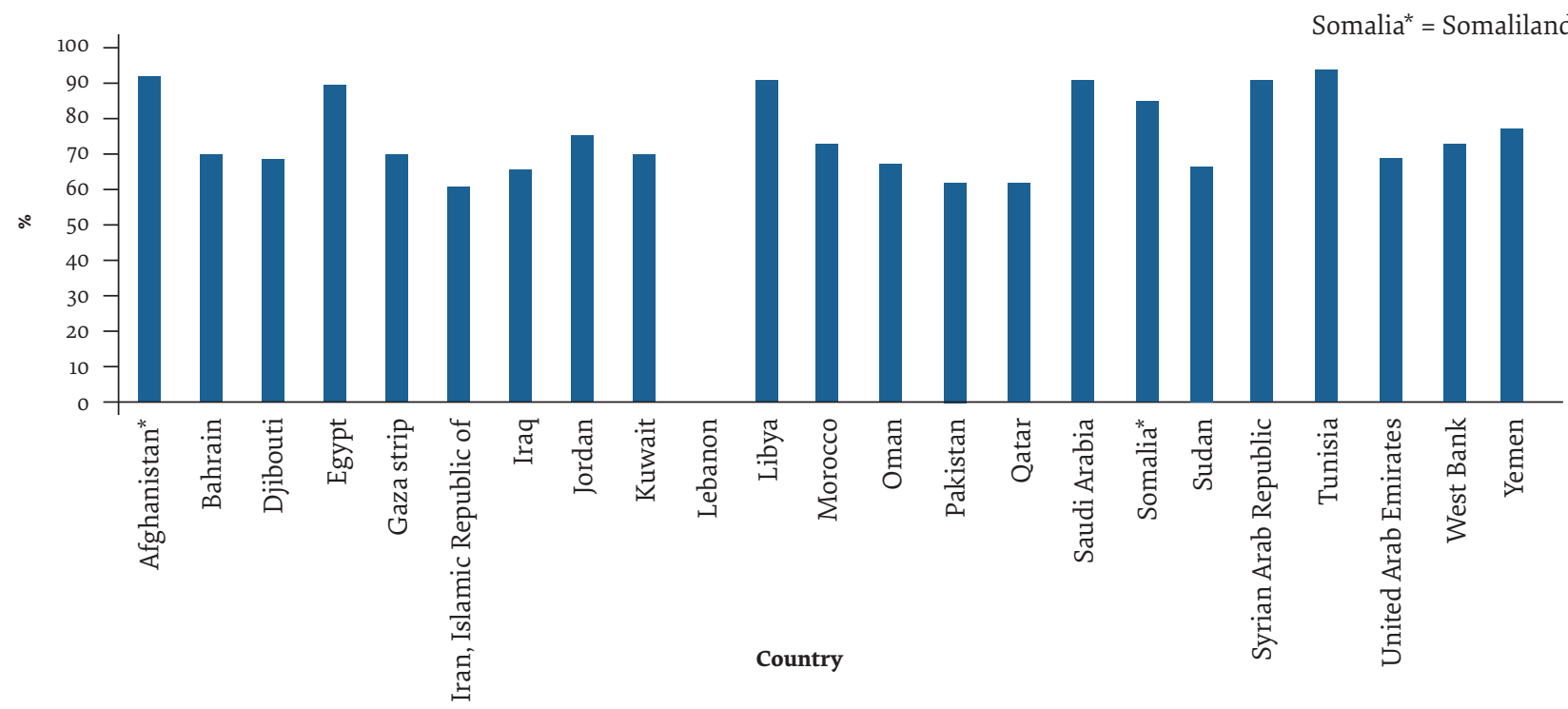


This can be done by looking into all entertainment productions in the Region - whether TV series or movie, or aired specifically in Ramadan or not. Moreover, productions from all countries must be considered. This is crucial for the successful implementation of controls because of the now widespread use of satellite channels. The proliferation of satellite TV has meant that the airing of any TV production is no longer limited to its country of production. Rather, TV series have become cross-border, transnational products.

The 2014 EMRO consultation report proposed several actions (1) that are in line with the recommendations of the WHO publication Smoke-free movies: from evidence to action (11). The most important of these is the regulation of tobacco presence in movies and TV productions through the full implementation of Article 13 of the WHO FCTC and its Guidelines on tobacco advertising promotion and sponsorship (12), which calls for a comprehensive ban on tobacco advertising, promotion and sponsorship. Such an intervention has worked well in other countries, stating that: "policies that prohibit product placement may help explain differences in content across nationally produced films. For example, relatively lower levels of tobacco in US films are likely due to the 1997 prohibition of tobacco product placement, after which tobacco portrayals in US films declined" (13).

The consultation report went on to emphasise the simultaneous need to continue monitoring tobacco use in TV productions and films and to regulate TAPS in drama, through legally binding declarations of interests that confirm producers have not received, and will not receive, any funds from the tobacco industry. Furthermore, the report underlined the importance of obligatory adult ratings for movies with high levels of tobacco placement and the establishment of regional observatories to monitor tobacco use in TV and films, such as the one established by the Egyptian Fund for Combating and Treatment of Addiction and Drug Abuse.

To fulfil the proposed measures, the consultation report suggested that countries engage TV producers and film-makers in the discussion and decision-making process. While following these recommendations, it is important for countries to avoid voluntary agreements and approaches as these are not effective. Indeed, in 2014 the Egyptian Fund for Combating and Treatment of Addiction and Drug Abuse issued a code of ethics for TV producers, with the purpose of banning tobacco use in TV productions. Unfortunately, the code did not work and, following its signature, tobacco use on TV continued at the same level as before, if not higher.
One of the key recommendations of the consultation report was to raise the issue to the WHO FCTC Conference of the Parties in order to seek global consensus on needed actions. This is particularly important in light of some claims that any attempt to control the TAPS phenomenon is against freedom of speech. It was this claim that hindered attempts to control on-screen tobacco use in other countries, as was the case in India (14).

The Conference of the Parties, in its Seventh Session (2016), discussed the issue of tobacco advertising, promotion and sponsorship in relation to the depiction of tobacco in entertainment media. The issue had been raised as an agenda item by Egypt on behalf of EMR Parties. The Conference of the Parties adopted a decision that recommended action at 2 levels (2): first, at the institutional level led by the WHO FCTC Secretariat; and second, at the national level led by the parties. In its recommendations for countries, the Conference of the Parties called for the following considerations:

- scaling up the implementation of WHO FCTC Article 13 and its Guidelines to achieve comprehensive coverage on both cross-border advertising and TAPS in entertainment media;

- monitoring the use of TAPS in entertainment media and cross-border advertising in accordance with national legislation and priorities" (15).

While the implementation of the institutional recommendations will benefit all countries and parties to the WHO FCTC, it remains important to follow up on national recommendations and to continue to collect national evidence on the status and practices of the tobacco industry. This includes the industry's tobacco promotion through TV productions and movies. In addition, the regular inclusion of this item on the Conference of the Parties agenda will highlight the importance of countries' attempts to control on-screen TAPS, while also offering political support for countries to take strong action. There is also a need for a knowledge, attitude and practice study on TAPS in films among filmmakers to understand better their position and, using evidence, engage them in controlling this practice in movies.

A comprehensive approach is essential for tobacco control. It is especially important to ban all TAPS, effectively execute the relevant legislation and not to leave any loopholes that the tobacco industry can exploit. This is the only way to move forwards and end the tobacco industry's use of TV productions and movies to promote their products and undermine national legislation bans on tobacco advertising, promotion and sponsorship.

\section{Acknowledgements}

The authors thank the team from the Egyptian Fund for Combating and Treatment of Addiction and Drug Abuse, led by Mr Amr Osman, for providing the results of the studies reviewed in this article.

Funding: None.

Competing interests: None declared. 


\section{Publicité en faveur du tabac, promotion et parrainage dans les médias du divertissement : un phénomène requérant un contrôle renforcé dans la Région de la Méditerranée orientale}

\section{Résumé}

La consommation de tabac et le placement des produits du tabac dans les productions télévisées et au cinéma représentent une façon de promouvoir le tabagisme tout en contournant les interdictions de publicité en faveur du tabac existantes dans la plupart des pays. Le fait que de telles productions soient largement diffusées et vues par des millions de personnes, notamment des enfants et des jeunes, est préoccupant. La présente étude passe en revue les données sur la publicité en faveur du tabac, la promotion et le parrainage à la télévision et au cinéma dans la Région de la Méditerranée orientale, ainsi que les façons de les combattre. En Égypte, les données montrent que l'utilisation des produits du tabac chez les acteurs, notamment chez les actrices, dans les programmes diffusés pendant le Ramadan entre 2015 et 2017 est considérable et a connu une hausse. Une étude des films iraniens en 2015 a montré que les scènes où l'on voyait des acteurs fumer avaient augmenté. En 2014, le Bureau régional de l'OMS pour la Méditerranée orientale a organisé une réunion de consultation sur la publicité en faveur du tabac, la promotion et le parrainage dans les œuvres dramatiques. La consultation a recommandé de réglementer la présence des produits du tabac au cinéma et à la télévision au moyen de l'application complète de l'article 13 de la Convention-cadre de l'OMS pour la lutte antitabac, ainsi que de faire état du problème lors de la Conférence des Parties à la Convention-cadre de l'OMS pour la lutte antitabac. En 2016, la Conférence des Parties a appelé les Parties à envisager d'intensifier l'application de cet article, ainsi que de procéder à un suivi de la publicité en faveur du tabac, de la promotion et du parrainage dans les médias du divertissement, conformément à la législation nationale. Une approche globale est essentielle pour mettre un terme à l'utilisation des productions télévisées et du cinéma par l'industrie du tabac dans le but de faire la promotion de ses produits.
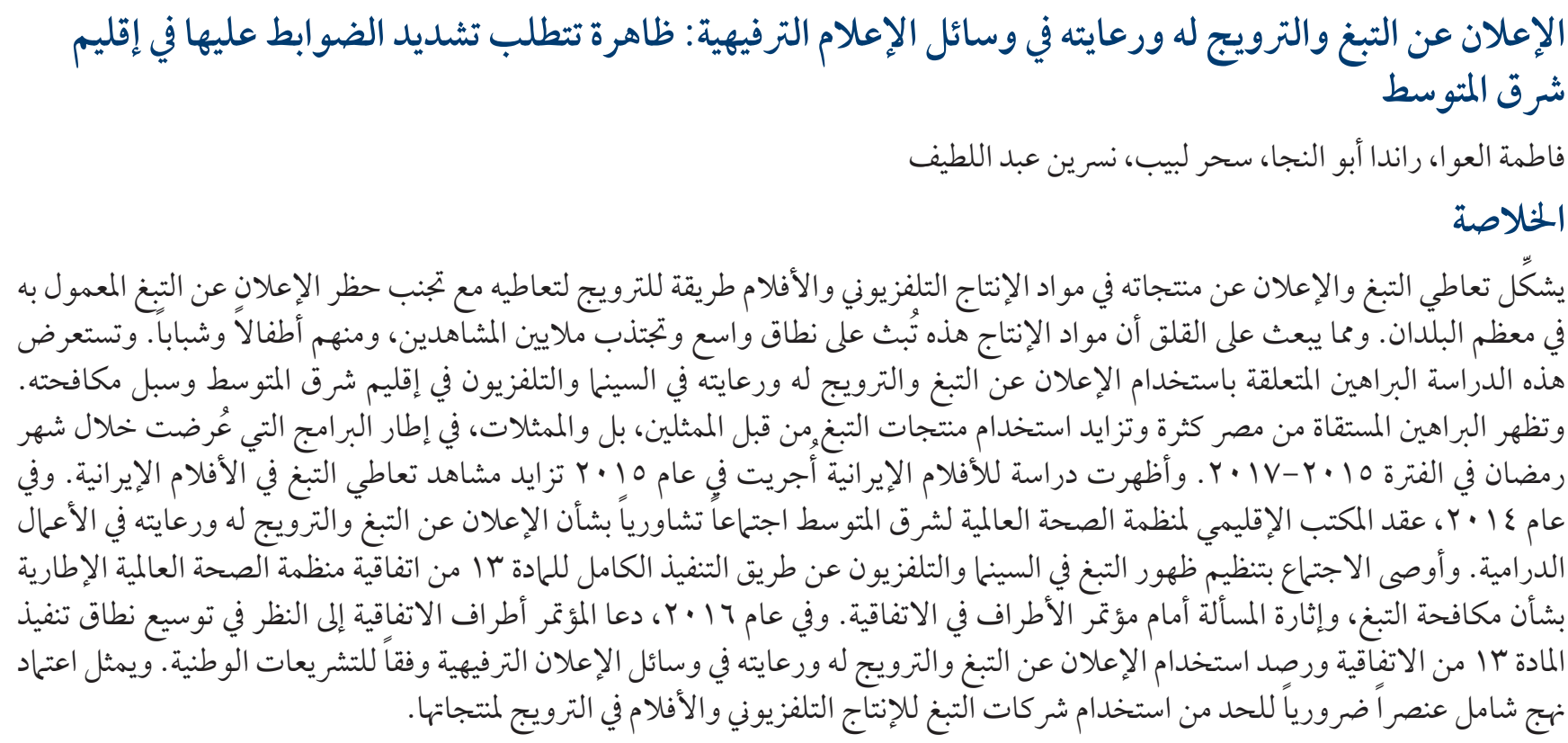

\section{References}

1. Report on the consultative meeting on tobacco advertising, promotion and sponsorship (TAPS) in drama. Cairo, Egypt, 25-24 August 2014. Cairo: World Health Organization Regional Office for the Eastern Mediterranean; 2014 (http://applications.emro. who.int/docs/IC_Meet_Rep_2014_EN_16244.pdf?ua=1, accessed 4 January 2018).

2. WHO Framework Convention on Tobacco Control. Conference of the Parties. Decision. Tobacco advertising, promotion and sponsorship: depiction of tobacco in entertainment media. 12 November 2016 (http://www.who.int/fctc/cop/cop7/FCTC_COP5_7_ EN.pdf?ua=1, accessed 4 January 2018).

3. Analysis of the presentation of drug use in drama series in Ramadan. تحليل التناول الدرامي لمشكلة تعاطي المخدرات رمضان Cairo: Egyptian Fund for Control of Drugs; 2017-2015 (http://drugcontrol.org.eg/ResearchResources/ResearchAndStudies/StudiesList/Item_546, accessed 4 January 2018).

4. Heydari G, Ebn Ahmady A, Lando HA, Chamyani F, Masjedi MR, Shadmehr MB, et al. Smoking display-time trends in Iranian movies. Health \& Social Work. 2015 November 4)40;1):e156-e161. https://doi.org/10.1093/hsw/hlvo66

5. Smouldering progress in tobacco control. Lancet. 2016 Feb 619:(10019)387;13. http://dx.doi.org/10.1016/S9-00315(16)6736-0140 PMID:26876701

6. WHO global report on trends in prevalence of tobacco smoking 2015. Geneva: World Health Organization; 2015 (http://apps.who. int/iris/bitstream/9789241564922/1/156262/10665_eng.pdf?ua=1, accessed 13 January 2018). 
7. Heydari G. Iranian audience poll on smoking scenes in Persian movies in 2011. Int Prev Med. 170-164:(2)5;2014.

8. Gendall P, Hoek J, Edwards R, Glantz S. Effect of exposure to smoking in movies on young adult smoking in New Zealand. PLoS One. 2016 Mar 3)11;9):e0148692. http://dx.doi.org/10.1371/journal.pone.0148692 PMID: 26960189.

9. Tynan MA, Polansky JR, Titus K, Atayeva R. Stanton A, Glantz. Tobacco use in top-grossing movies - United States, 2016-2010 MMWR Morb Mortal Wkly Rep. 2017 Jul 86-681:(26)66;7. http://dx.doi.org/10.15585/mmwr.mm6626a1 PMID:28683057.

10. Preventing tobacco use among youth and young adults - a report of the Surgeon General. Atlanta (GA): US Department of Health and Human Services, Centers for Disease Control and Prevention, National Center for Chronic Disease Prevention and Health Promotion, Office on Smoking and Health; 2012 (https://www.surgeongeneral.gov/library/reports/preventing-youthtobacco-use/full-report.pdf, accessed 4 January 2018).

11. Smoke-free movies: from evidence to action, third edition. Geneva: World Health Organization; 2015 (http://apps.who.int/iris/bits tream/9789241509596/1/190165/10665_eng.pdf?ua=1, accessed 4 January 2018).

12. Guidelines for implementation of Article 13 of the WHO Framework Convention on Tobacco Control (Tobacco advertising, promotion and sponsorship) (http://www.who.int/fctc/guidelines/article_13.pdf?ua=1, accessed 4 January 2018).

13. Barrientos-Gutierrez I, Kollath-Cattano C, Mejía R, Arillo-Santillán E, Hanewinkel R, Morgenstern M, et al. Comparison of tobacco and alcohol use in films produced in Europe, Latin America, and the United States. BMC Public Health. 2015 Nov 15:1096;3. http://dx.doi.org/10.1186/s-2378-015-12889x PMID: 26526859

14. Arora M, Mathur N, Gupta VK, Nazar GP, Reddy KS, Sargent JD. Tobacco use in Bollywood movies, tobacco promotional activities and their association with tobacco use among Indian adolescents. Tob Control. 2012 Sep;7-482:(5)21. http://dx.doi. org/10.1136/tc.2011.043539 PMID: 21730099

15. Report of the seventh session of the Conference of the Parties to the WHO Framework Convention on Tobacco Control. Delhi, India, 12-7 November 2016 (http://www.who.int/fctc/cop/cop7/FINAL_COP7_REPORT_EN.pdf?ua=1, accessed 4 January 2018). 